\title{
D. J osé Botelho de Mattos, arcebispo da Bahia, e a expulsão dos jesuítas (1758-1760)
}

\section{J osé Botelho de Mattos, archbishop of Bahia, and the Expulsion of the J esuits (1758-1760)}

\author{
EVERGTON SALES SOUZA ${ }^{1}$ \\ Doutor em História Moderna e Contemporânea - Université Paris-Sorbonne (Paris IV) \\ Departamento de História - Universidade Federal da Bahia \\ evergtons@yahoo.com.br
}

RESUMO No século XX, a historiografia luso-brasileira fez do arcebispo da Bahia, D. J osé Botelho de Mattos (1678-1767), um dos paladinos da resistência às políticas reformadoras de D. J osé e do seu ministro, Sebastião J osé de Carvalho e Melo. Num primeiro momento, o presente artigo busca recompor os passos dessa construção historiográfica. Em seguida, baseado em farto material documental, parcialmente inédito, procura esboçar uma nova interpretação a respeito do papel desempenhado pelo arcebispo na conjuntura marcada pela expulsão dos jesuítas da Bahia e sobre os motivos da sua resignação ao arcebispado.

Artigo recebido em: julho/2008.

1 Sou grato aos valiosos comentários e sugestões feitos pelos colegas Bruno Feitler e J osé Pedro Paiva que gentilmente aceitaram ler uma versão preliminar do presente artigo. 
Palavras-chave Expulsão dos jesuítas - Igreja e Estado no Brasil do século XVIII - História e memória.

ABSTRACT Portuguese and Brazilian historiography in the twentieth century turned the archbishop of Bahia, D. J osé Botelho de Mattos (1678-1767), into a champion of the resistance against the reformation policies of King J osé and his minister Sebastião J osé de Carvalho e Melo. This article attempts first to analyze this historiographic construction and search its origins. Then, based on a wide scope of original documents, it seeks to draft a new interpretation of Botelho de Mattos' role as regards the J esuits' expulsion from Bahia in 1760, as well of the true reasons for his resignation.

Keywords Expulsion of the J esuits - Church and state in Brazil seventeenth century - History and memory.

Tem sido um lugar comum na historiografia luso-brasileira tratar o oitavo arcebispo da Bahia, D. J osé Botelho de Mattos, como fazendo parte do grupo de prelados perseguidos por Sebastião J osé de Carvalho e Melo². Na introdução que escreve ao livro de J osé Caeiro - cujo manuscrito data de 1776 -, Luis Gonzaga Cabral traça um paralelo entre o prelado baiano e D. Miguel da Anunciação, bispo de Coimbra que, após publicar uma pastoral condenando a circulação e leitura de determinados livros, foi encarcerado por ordem de D. J osé e de seu ministro. Segundo este autor, o prelado baiano não teria cedido às investidas de Carvalho e Melo para que publicasse uma pastoral visando "denegrir o bom nome dos jesuítas". Diz ainda que, "a coragem do prelado deu ao Brasil, nessa hora de acobardamento deprimente, a glória de apresentar à Igreja e ao mundo essa figura, digna de seu heróico irmão de além-mar, o Bispo Conde de Coimbra". Quanto à resignação do arcebispado, observa o mesmo autor que Botelho de Matos ter-se-ia demitido "para evitar uma situação cismática".

O texto do jesuíta Luis G. Cabral sobre o arcebispo da Bahia nem sempre encontra eco no testemunho de Caeiro, que, embora enalteça em alguns momentos a anterior amizade do prelado com os jesuítas, não deixa de estranhar algumas de suas atitudes na conjuntura da expulsão dos mesmos do Império português. É o caso, notadamente, da distribuição pelo arcebispo de vários exemplares da Relação Abreviada da República dos J esuítas. Caeiro demonstra seu descontentamento em relação ao

2 Para um melhor conhecimento da biografia desse prelado, ver Rubert, Pe. Arlindo. "D. J osé Botelho de Mattos (1678-1767), 8o arcebispo da Bahia (no tricentenário de seu nascimento)", RIHGB, n.87, 1978, pp.105-123. 
arcebispo em função dele ter enviado exemplares "não só aos superiores dos religiosos, senão também a gente nobre, deixando a todos admirados de que um homem certamente piedoso praticasse uma ação, que revelava bem pouca piedade"3. Contudo, faz em seguida uma ressalva:

\begin{abstract}
“Tenhamos, porém só comiseração para com este venerando velho, já octogenário, e por isso mesmo mais exposto a impressionar-se com os furores de Carvalho; e o que devemos ter presente é tudo quanto ele galharda e varonilmente, praticou em prol dos jesuítas, pois o fez levado pelos sentimentos e impulsos do seu coração convicto; e se depois fraqueou e cometeu para com eles aquela grave injustiça, isto se deve atribuir ao apavoramento do seu espírito, perturbado por aqueles terrores"4.
\end{abstract}

Como se verá mais adiante, Caeiro não foi o único a fazer referência à idade provecta de Botelho de Matos para explicar algumas de suas atitudes. Por ora interessa-nos sobretudo compreender as razões que levaram historiadores a fazer de Botelho de Mattos um símbolo da resistência antipombalina. Como é sabido, o manuscrito latino de Caeiro, conservado no arquivo dos inacianos em Roma, foi impresso somente na década de 30 do século passado. Embora possa ter contribuído para alimentara idéia de que o prelado baiano fora perseguido pelo ministro de D. J osé por resistir às suas ordens antijesuíticas, a obra de Caeiro seguramente não pode ser identificada como a fonte primordial dessa idéia. Nas Memórias do Marquez de Pombal, publicadas em francês, no ano de 1784, faz-se referência ao fato de que uma gazeta de Amsterdam havia cometido a injúria de supor que D. J osé Botelho de Mattos era contrário às leis do monarca português e partidário dos jesuítas expulsos. Esta notícia, que as mesmas Memórias deixam subentender como plantada por jesuítas ou seus partidários, teria sido usada como pretexto para que Roma dilatasse a expedição das bulas necessárias à sagração de D. Manuel de Santa Inês como novo arcebispo da Bahia, fato que viria a contribuir para a ruptura das relações de Portugal com a cúria romana 5 .

3 Cf. Caeiro, J osé. J esuítas do Brasil e da Índia na perseguição do Marquês de Pombal, Salvador, Escola Tipográfica Salesiana, 1936, p.39. Nesta parte, Caeiro compara a atitude do bispo àquela mais sensata do Vice-Rei que, embora tivesse recebido a ordem de distribuir muitos exemplares da "República", "portou-se com mais critério, pois que espontaneamente não fez passar nenhum deles e apenas os deu aos que lhos pediram". Sobre o assunto ver nota 29.

4 Ibid.

5 Cf. Mémoires de Sébastien-J oseph de Carvalho et Melo, Comte d'Oeyras, Marquis de Pombal, Secrétaire d'État et premier Ministre du Roi de Portugal J oseph I. Tome Second. A Lisbonne, et se trouve à Bruxelles, Chez B. Le Francq, 1784, p.260, onde se lê : "Pendant que l'archevêque nommé faisoit solliciter l'expédition de ses bulles, arriva à Rome, une gazette d'Amsterdam, où l'on faisoit, sans aucun fondement, au premier archevêque Dom J oseph Botelho de Mattos, l'injure de le supposer rebelle aux loix de Sa Majesté très-fidele, \& fauteur des J ésuites expulsés // Cette fausse nouvelle, appuyée par des gens qui ne sont pas inconnus à la Cour de Lisbonne, parut suffisante au Ministre de Sa Sainteté pour suspendre l'expédition des bulles de Dom Manuel de Sainte-Agnès... ". 0 mesmo texto encontra-se reproduzido em outras obras, dentre as quais a de Simão J osé da Luz Soriano, História do reinado de El-Rei D. J osé e da Administração do Márquez de Pombal, Lisboa, Typographia Universal de Thomaz Quintino Antunes, 1867, t. II, pp.448-449. A mesma história também já havia sido referida por Fr. Claudio 
Um testemunho de fins do século XVIII, o de Luis dos Santos Vilhena, não entra em detalhes sobre as razões da resignação do bispado por Botelho de Mattos, mas informa que ele se retirou para o sítio de Itapagipe, onde reedificou a igreja que ali já havia e construiu um palacete onde residiú. Este dado, como notou Braz do Amaral, um dos anotadores da obra de Vilhena, entrava em choque com a idéia de que o prelado havia morrido na pobreza ${ }^{7}$ - assunto ao qual retornaremos adiante.

Escrevendo em inícios do século XIX, o inglês Robert Southey abordou 0 assunto apresentando duas fases distintas na ação do prelado baiano no processo contra os jesuítas. Na primeira, o arcebispo teria obedecido fielmente todas as ordens vindas da corte. Na segunda fase, quando, na qualidade de visitador e reformador da ordem, deveria dar conta à corte das supostas irregularidades cometidas pelos jesuítas, teria, ao contrário, atestado suas condutas irrepreensíveis e beneméritas ${ }^{8}$. Alguns anos depois da publicação, no Brasil, da obra de Southey, o padre Carlos Augusto Peixoto d'Alencar numa obra sobre os bispados e bispos do Brasil limitava-se a inferir que a perseguição aos jesuítas teria sido o maior motivo da resignação do bispado por Botelho de Mattos ${ }^{9}$. Já Cândido Mendes de Almeida escreveu numa nota em que se referia à "dignidade e independência" de D. Miguel da Anunciação, que D. J osé Botelho de Mattos - e o bispo do Maranhão, D. Antônio de S. J osé - manifestavam silenciosamente o seu desgosto para com a política antijesuíta da corte. ${ }^{10}$ Não deixa de ser interessante notar que, na pena de um ultramontano como Cândido Mendes de Almeida, 0 arcebispo apareça ao lado de D. Miguel da Anunciação, mas sem que seja afirmada sua condição de paladino da resistência a Pombal ou de vítima da sua perseguição. Em outras palavras, ainda não havia chegado a termo a construção da memória do prelado baiano enquanto herói antipombalino. A ausência de referência ao prelado no opúsculo sobre a lgreja da Bahia escrito pelo abade Romualdo Maria de Seixas Barroso, publicado em Roma, em $1870^{11}$, também parece corroborar nossa hipótese de uma construção tardia dessa memória do antístite baiano.

da Conceição, Gabinete histórico que a sua Magestade Fidelíssima o Senhor Rei D. Miguel I. em o dia dos seus felic íssimos annos 26 de outubro de 1830 offerece Fr. Cláudio..., contém os annos de 1760, 1761 e 1762, Lisboa, Na Impressão Régia, 1830, t. XV, pp.24-28.

6 Cf. Vilhena, Luis dos Santos, A Bahia no século XVIII, Salvador, Editora Itapuã, 1969, 3 vols., vol.2, pp.456-457.

7 lbid., pp.472-473. É importante lembrar que as notas de Braz do Amaral à edição do livro de Vilhena datam de 1922.

8 Cf. Southey, R. História do Brasil, Belo Horizonte, São Paulo, Ed. Itatiaia, Edusp, 1981, vol.3, pp.298-300 [A 1a ed. inglesa saiu entre 1810 e 1819. Já a primeira edição brasileira data de 1862].

9 Carlos Augusto Peixoto d'Alencar, Roteiro dos bispados do Brasil e dos seos respectivos bispos, desde os primeiros tempos coloniaes até o presente, Ceará, Typ. Cearense, 1864, pp.61-62, escreve: 'J ulga-se com todo fundamento, que a causa do desgosto deste prelado, para entregar o governo da Diocese ao corpo capitular, e recolher-se ao silencio, foi a grave impressão moral que recebeo com a injusta perseguição dos jesuítas".

10 Cf. Almeida, Cândido Mendes de. Direito civil ecclesiastico brazileiro antigo e moderno..., Rio de J aneiro, B. L. Garnier Livreiro Editor, 1866, t. I, p.XCIV.

11 Cf. Barroso, Romualdo M. de Seixas, Quelques mots sur l'Église de Bahia (Brésil), Roma, Imprimerie Salviucci, 1870 . 
A situação é bem diferente no século XX. Rocha Pombo em sua História do Brasil, cuja primeira edição data de 1905 (uma edição em grande formato, em 10 volumes, foi publicada entre 1915 e 1917), destaca Botelho de Matos como um daqueles que "procederam generosamente" com os jesuítas, deixando transparecer que o prelado havia se recusado a executar as ordens da coroa acerca dos jesuítas ${ }^{12}$. Em Portugal, Fortunato de Almeida publica sua monumental História da Igreja em 1910, nela diz ter sido 0 arcebispo perseguido pelo Marquês de Pombal por não ter colaborado na guerra que este movia contra os jesuítas, tendo resignado ao arcebispado em função dessas perseguições ${ }^{13}$. Escrevendo nos anos 1920, o professor da Faculdade de Medicina da Bahia, J osé Eduardo F. de Carvalho Filho, afirma que o "forte e justiceiro" D. J osé Botelho de Mattos teria preferido perder "sua cadeira prelatícia a praticar a injustiça que lhe impunha o governo da metropole contra os jesuítas"14. Diz também que o prelado havia se recusado a cumprir as ordens de Carvalho e Melo por ter "'achado os jesuítas irrepreensíveis, mui úteis e beneméritos', no que foi acompanhado por um attestado firmado por mais de 80 assignaturas do que havia de mais selecto na Diocese e entre ellas a do irmão do Patriarcha de Lisboa ${ }^{15}$, 'não cumpriria a ordem de suspender de suas funcções os J esuitas, porque, tendo uma residencia de 19 annos na sua Sé e habilitado a reconhecer 0 verdadeiro caracter destes padres e a appreciar o bem que fazem, não podia em consciencia ser o instrumento de reduzir ao silencio homens cujos serviços tanto aproveitavam ao seu rebanho'"'16. Embora esteja supostamente citando um texto escrito por Botelho de Mattos, não fornece qualquer referência que permita a identificação da fonte. É necessário também notar que não é grande a fiabilidade das informações levantadas por Carvalho Filho, o que fica patente, por exemplo, ao escrever "que o nobre gesto a favor dos jesuítas custou-lhe [a Botelho de Mattos] a perda da diocese em $1766^{\prime 17}$. Ora, sabemos que a carta de resignação do arcebispado data de 1759 e que, no ano seguinte, com a aceitação do rei, o prelado deixou a administração de sua arquidiocese.

12 Cf. Rocha Pombo, J. F. da. História do Brasil, Rio de J aneiro, W. M. Jackson inc. editores, 1935, 10 vol., vol. II, pp.383-384.

13 Cf. Almeida, Fortunato de. História da Igreja em Portugal, Porto, Portucalense Editora, 4 vol., 1967-1971, vol. II, p.684 e vol. III, p.604. Vale notar que uma das fontes citadas pelo autor nesta edição, preparada por Damião Peres e que segue àquela de 1930, são as Memórias históricas e políticas da província da Bahia de Accioli.

14 Cf. Carvalho Filho, J osé Eduardo F. de, A devoção do Senhor J. do Bom-Fim e sua história, Bahia, Typ. de São Francisco 1923, p.16.

15 Esta informação aparece também em Caeiro, op. cit., p.67: "O primeiro de todos a depôr foi Manuel Saldanha, irmão carnal do Cardeal Saldanha, depois foi J osé Mirales, cujo filho jesuita pouco antes havia sido expulso da ordem; seguiram-se-lhes os principais da cidade [...] Por esta forma foram interrogadas oitenta testemunhas; e entre tanto nem um só houve, que dissesse exercerem os jesuítas qualquer sorte de comercio, mas pelo contrário todos asseguraram ser isso uma calúnia contra eles levantada".

16 Cf. Carvalho Filho, J osé Eduardo F. de, op. cit., pp.124-125. Rocha Pombo, op. cit., vol.Il, pp.383-384, também faz referência ao assunto.

17 Ibid., p.127. 
Serafim Leite, em sua História da Companhia de J esus, também se reporta ao prelado em termos elogiosos. No tomo $\mathrm{V}$ diz que "o grande arcebispo, D. J osé Botelho de Matos, teve a coragem de sustentar os seus Religiosos, e foi obrigado a resignar por ordem de EI-Rei"18. No prefácio ao tomo VII lembra que "felizmente, para honra da humanidade e da religião, há sempre quem reaja contra o ambiente artificial das perseguições transitórias e acompanhe com corajosa simpatia os que são injustamente ultrajados. E se por isso tiveram que padecer, como entre outros o glorioso Arcebispo da Bahia, Botelho de Matos, a história é justiceira e faz hoje desse Prelado, 0 orgulho da igreja primaz do Brasil"19. Duas idéias parecem cristalizar-se: a da coragem do arcebispo que enfrentou a coroa para defender os jesuítas e a da perseguição que teria sofrido por este motivo.

Na mesma década de 1940, Pedro Calmon, em sua História do Brasil, adere à idéia da resistência silenciosa de Botelho de Mattos, fazendo uso do testemunho de Caeiro. Sem maiores alaridos, é verdade, o historiador afirma que "a relutância do arcebispo em prestar-se ao processo contra os jesuítas" estaria na origem de seu pedido de demissão ${ }^{20}$.

Escrevendo na década de 1950, Monsenhor Paulo Florêncio da S. Camargo também colocou Botelho de Matos na lista das "vítimas do ódio de Pombal". Segundo este autor, embora o arcebispo tenha substituído "nas aldeias os jesuítas pelo clero secular" e tenha enviado os padres estrangeiros da Companhia para Portugal, "quando foi da questão do comércio atribuído aos religiosos, ele enviou ao Reino "um sincero atestado" assinado por 80 pessoas das mais eminentes da Baía, negando-o". Por causa do seu "jesuitismo perdeu a primazia e mais o rendimento total da mitra. Com 80 anos de idade, ficou à mercê da caridade pública"21.

Em 1960, Américo J acobina Lacombe diz que o arcebispo não se teria prestado ao papel que o governo esperava dele na campanha contra os jesuítas e, por este motivo fora forçado a resignar. Segundo o mesmo autor, "acompanhou o prelado quase toda a cidade. Retirou-se o arcebispo renunciante para a ermida da Penha, onde terminou tristemente seus dias. Foi dos poucos elementos do clero que ousara opor-se aos desígnios pombalinos"22.

Na História da Igreja do Brasil do CEHILA, apenas uma pequena notícia dando conta de que o prelado baiano, ao não agir contra os jesuítas como queria a corte, havia sido um daqueles bispos que tiveram coragem de agir

18 Leite, Serafim, História da Companhia de J esus no Brasil, 10 tomos, Lisboa: Liv. Portugália, Rio de J aneiro: Instituto Nacional do Livro, Liv. Civilização Brasileira, 1938-1950, t. V, p.104.

19 Ibid., t. VII, p.X.

20 Cf. Calmon, P. História do Brasil, Rio de J aneiro, J osé Olympio, vol. 4, 1961, p.1152

21 Cf. Camargo, Paulo Florêncio da Silveira, História eclesiástica do Brasil, Petrópolis, Vozes, 1955, pp.248-250.

22 Cf. Lacombe, Américo J. "A Igreja no Brasil colonial", in Holanda, Sérgio Buarque de. Históriga Geral da Civilização Brasileira. A época colonial, São Paulo, Difel, 1960, t.l, vol.2., p.62. 
contra os poderosos ${ }^{23}$ - opinião que pode ser útil a certo discurso pastoral, mas evidentemente desprovida de sentido e anacrônica quando se trata de uma análise historiográfica.

Thales de Azevedo consagra a Botelho de Mattos uma página de seu Igreja e Estado em tensão e crise. Nela, sintetiza os principais argumentos utilizados na construção da memória do arcebispo como símbolo da luta contra Carvalho e Melo e vítima da sua perseguição. Com efeito, os temas mais recorrentes na caracterização do arcebispo aparecem todos no texto de Thales de Azevedo:

\begin{abstract}
"encarregado pelo cardeal Saldanha de reformar a Companhia de J esus no Brasil, investiga conscienciosamente a atuação dessa ordem e conclui pela malícia de algumas das imputações que se fazem à mesma. Ante as acusações de comércio aos jesuítas, toma posição em prol destes e envia ao reino 'um atestado sincero', subscrito por oitenta pessoas eminentes, que refutam tais denúncias. Esse documento irrita Lisboa, tanto mais que o prelado se recusa à insinuação de Sebastião J osé de Carvalho e Melo [...] de publicar uma pastoral contra os odiados religiosos. Em Lisboa o ministro leva ao cárcere por motivo idêntico D. Fr. Miguel da Annunciação, bispo de Coimbra, o qual só é libertado muitos anos depois, no reinado de Dona Maria. 0 arcebispo da Bahia não é preso, mas humilhado com a forçada renúncia, para evitar uma situação cismática, uma vez que uma parte do clero também se lhe opõe na circunstância. Essa facção, obediente ao govemante desautorizado, presta-se a dar o sino grande da catedral, anunciando a vacância da Sé arquiepiscopal. Demitido, em avançada idade, sem rendas e pobre, D. J osé recolhe-se à ermida da Penha, em Itapagipe, e aí falece aos 97 anos $^{24}$, deixando um nome que sobressai naquela "hora de acorbadamento deprimente", no julgamento do Pe. Luís Gonzaga Cabral (S.J .)..."25.
\end{abstract}

Como se vê, o autor associou a figura de Botelho de Mattos àquela de D. Miguel da Anunciação, ainda que para tanto tenha cometido um grave erro factual, pois o motivo do encarceramento do bispo de Coimbra, em 1768 , foi bastante diferente. Procurou, também, enaltecer sua atitude em defesa dos jesuítas e reforçar a imagem de um prelado idoso, humilhado e perseguido por Carvalho e Melo.

No tricentenário do nascimento de Botelho de Mattos, o saudoso Arlindo Rubert escreveu um artigo sobre o arcebispo da Bahia, no qual dedicou algumas páginas bem documentadas - como de costume neste grande historiador eclesiástico - ao estudo da ação do prelado na conjuntura marcada pela expulsão dos jesuítas e por sua resignação do arcebispado ${ }^{26}$. A

23 Hoornaert, E. et alii. História da Igreja no Brasil. Ensaio de interpretação a partir do povo, Petrópolis, Vozes, 1977, p.281.

240 autor comete um erro, pois Botelho de Mattos, batizado em 5 de novembro de 1678, morreu no dia 22 de novembro de 1767, com a idade de 89 anos. Cf. AHU, Castro e Almeida, cx.41, doc.7748.

25 Azevedo, Thales de, Igreja e Estado em tensão e crise, São Paulo, Ática, 1978, pp.110-111.

26 Rubert, Pe. Arlindo. "D. J osé Botelho de Mattos (1678-1767), 8 arcebispo da Bahia (no tricentenário de seu nascimento)", RIHGB, n. 87, 1978, pp.105-123. As informações deste artigo são, em boa medida, retomadas pelo mesmo autor em A Igreja no Brasil, Santa Maria, Palotti, 1988, pp.26-34 
partir de seu estudo, alguns fatos em torno desses eventos ficaram mais bem estabelecidos, porém a interpretação típica da história eclesiástica, por vezes carregada de um tom demasiado apologético, compromete em alguma medida a compreensão dos problemas que ora pretendemos abordar.

Mais recentemente, Caio Boschi, num texto de síntese sobre o episcopado e a Inquisição no Império português, resumiu a atitude do prelado baiano como uma recusa a pôr fim às atividades da Companhia em sua arquidiocese. A renúncia ao arcebispado estaria ligada a esta sua posição e à sua tentativa de não sofrer alguma represália27. Este modo de entender a renúncia do arcebispo difere um pouco daquele apresentado por Samuel Miller, que pensa ter o arcebispo resignado à sua Sé sob ameaças - e que questiona a própria renúncia por não ter encontrado a carta de resignação de Botelho de Mattos ${ }^{28}$. Entretanto, em seu importante livro sobre 0 episcopado de Portugal e do Império, J osé Pedro Paiva corrige Miller, assinalando que a carta de renúncia firmada pelo prelado baiano encontra-se no processo consistorial do arcebispo seguinte, D. Frei Manuel de Santa Inês ${ }^{29}$.

Fabrício Lyrio Santos em sua dissertação de mestrado sobre a expulsão dos jesuítas também escreveu algumas páginas sobre a atuação do prelado baiano, inclinando-se a corroborar a tese de que o arcebispo fizera o que pôde em favor dos jesuítas, razão pela qual teria sido "premiado" com o afastamento do cargo e o confinamento numa pequena capela do subúrbio da cidade ${ }^{30}$. Embora proponhamos aqui uma interpretação diferente da deste autor, é importante reconhecer que ao fazer uso de vários documentos, ele contribuiu para uma melhor compreensão da ação do prelado naquela conjuntura. 0 conhecimento de outros documentos seguramente ter-Ihe-ia permitido matizar sua visão acerca dos posicionamentos do arcebispo da Bahia no episódio, fazendo com que interpretasse de modo diferente alguns indícios. Por exemplo:

27 Cf. Boschi, Caio. "Episcopado e Inquisição", in Bethencourt, F. e Chaudhuri, K. História da Expansão Portuguesa, Lisboa, Círculo de Leitores, 1998, vol. 3, pp.380 e 382.

28 Miller, S. J. Portugal and Rome c. 1748-1830. An aspect of the catholic enlightenment, Roma, Università Gregoriana Editrice, 1978, p.99. O problema da resignação sob ameaça, que, como referimos acima, já havia sido aventado numa gazeta holandesa setecentista, reaparece nas anotações de Braz do Amaral à obra de Ignácio Accioli, em 1937. Cf. Accioli, Ignácio... de Cerqueira e Silva \& Amaral, Braz do, Memórias históricas e políticas da província da Bahia. Salvador: Imprensa Oficial, 1919-1940. 6 vol. Ver vol.5, p.313, onde, antes de transcrever a carta de renúncia de Botelho de Mattos, diz: "Renúncia do Arcebispo que parece ter sido forçada".

29 Cf. Paiva, J osé Pedro. Os bispos de Portugal e do Império 1495-1777. Coimbra, Imprensa da Universidade de Coimbra, 2006, pp.547-548. O Professor Paiva teve a gentileza de nos comunicar a transcrição da carta de renúncia do arcebispo da Bahia, cujo teor ora publicamos: “Dom J oseph Botelho de Mattos arcebispo metropolitano do arcebispado da Bahia do Conselho de Sua Magestade fidelissima que Deus goarde. // Por me achar com idade mayor de outenta annos e por causa della e dos achaques habituaes que padeço, sentir ja muyto debilitados os sentidos, potencias e forças naturaes e me ver inhabilitado a cumprir como devo as obrigações de arcebispo com prejuizo das almas dos meus subditos, do serviço de Deus e de el Rey meu senhor e de minha alma, pello presente allvará faço desistencia, demissão, renuncia ou como em dereyto melhor nome ou lugar haja desta dignidade e arcebispado com seus pertences e annexas nas reais do dito senhor [sic] para que como governador e perpetuo administrador que he do mestrado, cavalaria e ordem de Nosso Senhor J esus Christo eleija e nomee sucessor, para cujo effeyto hey aqui por expressas declaradas quaiesquer clausulas que por dereyto necessarias forem. Bahia, J aneiro 31 de 1759. // (Selo). // (Assinatura) J oseph Botelho de Matos arcebispo da Bahia". Cf. ASV (Roma) - Archivio Concistoriale, Processus Consistoriales, vol.159, fl.297.

30 Santos, Fabricio Lyrio, Te Deum Laudamus. A expulsão dos jesuítas da Bahia (1758-1763), Salvador, UFBa, 2002, pp.96-100. 
em lugar de analisar a atitude do prelado em relação ao seqüestro dos bens da Companhia de J esus, que, em agosto de 1759, o conselheiro Barberino desejava executar, como uma defesa da ordem inaciana, poder-se-ia muito bem ver aí apenas uma posição cautelosa, marcada pela preocupação em não cometer excessos e seguir à risca as instruções da coroa e do cardeal reformador. Noutro momento, analisando uma carta de Botelho de Mattos ao Conde dos Arcos, datada de 29 de dezembro de 175931, na qual põe nas mãos do Vice-rei sua jurisdição a respeito da execução das ordens régias sobre os jesuítas, o autor toma-a como uma recusa do arcebispo a participar de diligências contra aqueles religiosos, o que nos parece, antes, uma atitude de apoio irrestrito às medidas tomadas pelo vice-reij ${ }^{32}$.

\section{Botelho de Mattos e a reforma dos jesuítas}

Em agosto de 1758, chegavam à Bahia as ordens para que se desse início à reforma da Companhia de J esus. 0 Cardeal Saldanha, reformador geral dos jesuítas em Portugal, havia delegado a função de visitador e reformador da ordem na Bahia ao arcebispo D. J osé Botelho de Mattos. Este aceitou a delegação e nomeou o seu vigário geral como seu secretário e adjunto. É provável que àquela altura o arcebispo ainda não suspeitasse dos fins últimos daquela reforma que se lhe encomendava, mas as cartas régias não deixavam margem a dúvida quanto à gravidade da situação e à desconfiança da coroa em relação à Companhia de J esus. Ademais, a ordem para que os aldeamentos administrados pelos jesuítas fossem transformados em vigararias com vigários escolhidos entre os clérigos seculares, constituía um sinal bastante claro das intenções da coroa de restringir a ação da Companhia. E, como se pode notar em carta que dirigiu ao rei no dia 19 de setembro 1758, o arcebispo procurou cumprir com rigor as determinações régias sobre a substituição dos jesuítas nos aldeamentos ${ }^{33}$.

31 Esta carta foi publicada pela primeira vez em Costa, Marcus de Noronha da, "A prisão e seqüestro dos padres da Companhia de J esus na Baía pelo Vice-Rei, o Vlo Conde dos Arcos". In: Anais do IV Congresso de História da Bahia. v. 1. Salvador: IGHBa; Fundação Gregório de Mattos, 2001.

32 Eis o teor da carta: IImo. e Exmo. Sr. Conciderando que para V. Exa. fazer executar as ordens de Sua Magestade Fidelissima acerca dos padres da Companhia, será necessario a V. Exa. conduzir a alguns a alguns (sic) às suas respectivas rezidencias, das quaes estão fora com licensa dos seus prelados, ou a titulo de vizitarem outros religiozos seus amigos ou tomarem ferias, e poderá [pede?] V. Exa. para este mesmo efeito o meu concurso; devo por esta dizer a V. Exa. Como digo que tudo o que mandar praticar para as cautelas que são indispensaveis para as suas condusões, será o mais ajustado ao serviso de Deus e ao de Sua Majestade, e que toda quanta jurisdisão tenho a este respeito será melhor administrada por V. Exa., a quem Deus guarde Bahia, Dezembro 29 de 1759.

33 Cf. AHU, Castro e Almeida, cx.20, doc.3674. A importância deste documento justifica que o publiquemos aqui em sua integralidade: As resoluções de Vossa Magestade, que me forão participadas por carta de oito de Mayo do corrente anno para neste arcebispado se darem aos Índios aldeados dentro dos seos limites parochos sacerdotes seculares, com omnimoda exclusão dos J esuítas; que até agora lhes administravão os sacramentos por tolerância de Vossa Magestade, e connivencia dos Prelados Diecesanos, são tão sanctas, e justas (como todas as mais) que para taes se entenderem basta saber que são de Vossa Magestade. Do Eminentíssimo cardeal Saldanha, Vizitador e Reformador Geral dos mesmos Religiosos nos Reynos de Portugal e dos Algarves, e em todos os Domínios de Vossa Magestade, me forão commettidas outras ao mesmo respeito como subdelegado seo nesta cidade, e todo este Arcebispado. Chegou a Nao de licença a este porto em vinte e sette do mês passado de Agosto, e o que nesta dependência se tem obrado até o dia de hoje fielmente exporey a Vossa Magestade, e he o seguinte. No dia vinte 
Na mesma carta o prelado relata tudo o que até ali tinha realizado para dar cumprimento às resoluções do monarca que lhe haviam sido comunicadas em carta de maio do mesmo ano. Contudo, a aceitação da delegação e o cuidado de pôr em execução as ordens régias não podem ser interpretados como indício de alguma parcialidade. São antes a atitude normal de um arcebispo cônscio da obediência devida ao seu soberano. Nesse sentido, o que parece realmente digno de nota é o cumprimento sem tergiversação, por parte do prelado baiano, das ordens que, posteriormente, Ihe chegaram da corte. Aí se encontra a razão dos queixumes de Caeiro acerca do procedimento de Botelho de Mattos. De fato, o cronista jesuíta não poupou críticas ao fato do arcebispo ter distribuído exemplares da sentença proferida a respeito da rebelião do Porto de 1757 e da Relação abreviada ${ }^{34}$, além de ter mandado fixar edital às portas dos templos comunicando que os membros de sua ordem estavam privados do exercício dos ministérios sagrados. Para Caeiro, "aquele Bispo, que por tanto tempo e com tanta energia de caracter se recusara a praticar semelhante baixesa, veio a cair nela sob os impulsos do terror". ${ }^{35}$ Mas deixemos de lado, por ora, os juízos passionais do autor jesuíta.

\section{A análise da correspondência entre o arcebispo e o Conselho Ultrama-}

e oito fis acceitação da commissão de Sua Eminência, e nomeação de Adjunto, e secretario da Reforma na pessoa do Padre Gonçalo de Souza Falcão, meu Vigário geral, por confiar delle dará do emprego a satisfação, que espero. No dia sette do prezente mês de setembro foy intimado o Breve; Acceytação de Sua Eminência, e nomeação de Adjuncto e Secretario ao Reytor, em auzencia do Provincial, e aos Religiosos do Colégio desta Cidade, com as mesmas formalidades, que se praticarão na Caza professa de S. Roque dessa Corte, sendo Executor da deligencia - Dezembargador Fernando J oseph da Cunha Pereyra. No dia nove se intimou o Mandamento de sua Eminência ao Provincial, e aos dittos religiosos, sendo executor oditto vigario geral, e finalmente no dia quatorze se intimou hum Decreto meo ao mesmo Provincial para ter prevenida a obediencia dos seos subditos, residentes nas Aldeas, para sairem dellas no mesmo ponto, que chegarem sacerdotes seculares com incumbencia de Parochos interinos, e de todo o sobredito remetto à Sua Eminencia Attestações em forma das quaes consta o estado, em que ao prezente se achão os dittos procedimentos. No dia de hontem se fez a primeira conferencia de Ordens, e propondo aos tres Ministros, que parecia conveniente publicar Edictaes para concurso, e remetter à Vossa Magestade as informações da sua resultancia, como se costuma nos primeyros provimentos das Igrejas deste Arcebispado, por ser a minha intenção nomear os approvados por Parochos interinos, por não privar de entrarem a concurso os sacerdotes, que houvesse de nomear antes delle, por lhes ser difficultoso o tornarem a esta cidade ao ditto fim, supostas as distancias, em que ficão alguas das Aldeas, seguindo-se o detrimento grave do pasto espiritual, que não deve faltar aos Indios: nemine discrepante, se resolveo, e assentou, que era justo, e prudente acordo preceder o ditto concurso. E ao tempo que forem para as Aldeas os dittos sacerdotes seculares se dará prompta execução as ordens de Vossa Magestade sobre as porções das congruas, e competentes passaes, que se lhes hão de assignar. Só se tem faltado a publicação da Carta de Vossa Magestade sobre a exclusão dos J esuitas, e introducção de sacerdotes seculares para Parochos dos Indios, a que Vossa Magestade manda fazer addições de direito, por estar a sua execução commetida ao mesmo Vigario geral, a quem na verdade tem faltado o tempo, suppostas as occupaçoens que lhe sobrevierão com a Reforma sobredita, e suas dependencias: porem brevissimamente se hade dar cumprimento a este preceito. Eeu o darey sempre com a devida obediencia aos de Vossa Magestade, cuja dilatada vida, e prosperidades incessantemente peço a Deos nos meos sacrificios. Bahia dezanove de Settembro de mil settecentos, e sincoenta e oito. // (Assinatura) J oseph Botelho de Mattos Arcebispo da Bahia".

34 Botelho de Mattos em carta de 2 de setembro de 1758, diz ao rei: "No seguinte dia ao em que se entregarão os saccos, fiz a repartição dos manifestos, e exemplares da sentença proferida, e executada na cidade do Porto pellos meos Ministros, cônegos e vigários desta Cide. e pellas comunidades della; e os poucos, que restarão, os tenho repartido por alguns vigários deste Arcebispado. Não o fiz pellos seculares, por serem poucos, e me persuadir, que essa repartição se fará por outra mão". Cf. AHU, Castro e Almeida, cx.19, n.3542.

35 Cf. Caeiro, op. cit., p.85. Na seqüência ainda escreve: "Nem o excusa de versatilidade o estado, em que se achavam os jesuitas nesse tempo; pois que o estarem então segregados, por ordem do Rei, do trato com os povos e guardados por sentinelas, os não tornava mais aptos para também o Prelado com a sua autoridade os proibir de exercitarem os seus ministérios. 0 que o assedio dos jesuítas, quando muito, provava, é que a intervenção do Prelado com aquela proibição se tornara já por aquele tempo desnecessária, ainda que as leis Iha facultassem". 
rino não deixa dúvida quanto ao esforço de Botelho de Matos para cumprir as ordens que lhe chegavam de Lisboa. Para além dos dois casos citados, é bom lembrar como o arcebispo se portou noutras ocasiões em que, fosse ele efetivamente um paladino do anti-pombalismo, poderia ter demonstrado alguma contrariedade no cumprimento do seu dever. Um bom exemplo é a expulsão dos jesuítas estrangeiros da Bahia, em 1759. Em carta de janeiro de 1759, o Conde dos Arcos, Vice-Rei do Brasil, informava a Tomé J . da Costa Corte Real, que o arcebispo havia realizado todas as diligências para obter a lista completa dos jesuítas estrangeiros residentes em seu arcebispado e tinha ordenado ao provincial da Companhia de J esus que fizesse com que todos eles se encontrassem recolhidos no colégio da ordem ${ }^{36}$. Aqui, mais uma vez, as ordens régias foram seguidas à risca pelo arcebispo.

0 procedimento de Botelho de Mattos também fica claro numa correspondência datada de 23 de maio de 1759, escrita de seu próprio punho e enviada ao Secretário de Estado Tomé J oaquim da Costa Corte Real. Nela, dando conta do andamento de algumas questões relativas à reforma dos jesuítas, escrevia o prelado:

\begin{abstract}
Vou continuando com o que pertence a Reforma dos Jezuitas; pouco depois da Paschoa fiz publicar em todas as freguezias desta cide. Hua carta pastoral obrigando a todos os meos subditos sob certas penas depuzecem perante mim o que souberem sobre os itens della. Alguns inda que poucos tem vindo denunciar, mas nenhum couza de substancia. Estamos a ver o que rezulta da Devaça, cuydo que será o mesmo, porq athequi falando com a verdade que devo, inda os não ouvi notar maes que de serem muyto sollicitos em adquirição de muytas fazendas que tem mettido em sy, ouço que precedeo Licença Real, mas cuydo a não terão de alguas grossas heranças q se lhe tem deyxado. ${ }^{37}$
\end{abstract}

Este trecho da carta poderia ser interpretado como uma "defesa" dos jesuítas, não fosse pela suspeita levantada quanto a algumas "grossas heranças" recebidas por eles. Ora, bem se vê que o arcebispo após relatar o que até ali tem apurado, mostra-se desconfiado sobre a regularidade de

36 Cf. AHU, Castro e Almeida, doc. 4008-9. Segue um extrato: “Pela informação do Reverendo Arcebispo constou no mesmo Concelho, que os Padres da Companhia, que se achavão, asim nos Collegios, como nas Aldeas do seu Arcebispado erão os seguintes: o Pe. J oão Brever, o Irmão Filosofo, Francisco Akins, os Irmãos leigos Thomas Luis, Mathias Piler, Pedro Massi, J oão Massi, J oão Rubiati, Thomas Brailla, Guilherme Lynceo, Francisco Xavier, 0 Pe. Thomas Lynceo e o Irmão Honorato Martins; e sendo intimada a ordem, que expedio o mesmo Concelho ao Provincial da Companhia para os fazer recolher das partes, em que se achassem, e por promptos a fazer viagem para esse Reyno na primeira occazião, que se offerecesse, promptissimamente assim o executou, como se verifica de irem embarcados na prezente Nao os primeiros dez Padres dos mencionados nesta mesma carta, e devendo tão bem ir os ultimos dous Padres Thomas Lynceo e Honorato Martins, estes por serem tão bem comprehendidos na determinação de Sua Magestade em carta de desanove de Mayo do anno passado, como representarão no concelho Ultramarino a avançada idade, em que se achavão, e sobre esta as perigozas queixas, que actualmente padecião, a vista dos seus requerimentos, e das exactas informações que precederão se tomou a determinação de deferir-lhe para outro tempo a sua viagem; dandose pelo mesmo Tribunal conta a Sua Magestade para que queira ser senvido determinar, se não obstante o deploravel estado, em que se achão, devem ser constrangidos a passar para esse Reyno".

37 AHU-Castro e Almeida, cx.22, doc.4115. Carta de Botelho de Mattos para Thomé J oaquim da C. Corte Real, de 23/05/1759. 
parte do patrimônio da Companhia de J esus em sua arquidiocese. Poderse-ia objetar que se tratava de uma estratégia para defender os jesuítas sem dar na vista, afinal o fato, até ali, era que nada havia encontrado contra aqueles religiosos e a desconfiança quanto às heranças poderia muito bem ser dissipada no futuro. Entretanto, a leitura de uma outra missiva, escrita três dias antes e remetida ao mesmo Secretário de Estado, parece tornar menos provável esta hipótese. Escrevia Botelho de Mattos:

Receby por primeira e segunda via os exemplares, que V. Exa. Me remetteo, em que se fazem manifestos os abuzos e usurpações dos Padres J esuitas, que promptamente fiz distribuir até onde chegarão pellos Conegos Capitulares, vigarios, e mais principaes pessoas desta cidade. Com esta repartição se fez mais a das sentenças, que tambem receby, proferidas na Suprema J unta da Inconfidência contra os principaes chefes e co-reos do sempre memorando sacrilegio, e execrando attentado comettido por obra contra a Real e Sempre Augusta pessoa de El Rey nosso Senhor A quem Deos por sua infinita misericordia foi servido livrar de tão manifesto perigo. 0 mesmo Senhor Permitta perzevar-lhe a vida e saude pellos annos, que seos fieis vassalos lhe dezejão e uniformemente lhe pedem ${ }^{38}$.

A suposta participação dos jesuítas no atentado contra o rei piorava a já crítica situação da Companhia, tornando ainda mais improvável alguma forma de apoio do arcebispo à sua causa. Contudo, um testemunho indireto - trata-se na verdade de um trecho de uma missiva do núncio de Portugal ao Secretário de Estado do Pontífice romano, de 20/11/1759 - dá conta de que o arcebispo teria escrito ao cardeal Saldanha uma carta na qual comunicava que não havia suspendido os padres da Companhia de confessar e pregar, além de afirmar não ter encontrado em sua arquidiocese causas para condenar os jesuítas como haviam encontrado outros bispos de Portugal ${ }^{39}$. Talvez haja algum exagero na notícia do núncio, mas é certo que 0 arcebispo teria efetivamente escrito algo sobre a utilidade dos jesuítas em sua arquidiocese, o que desagradou o governo e, provavelmente, apressou a decisão do monarca a respeito da aceitação do pedido de resignação do arcebispado feito por Botelho de Mattos ${ }^{40}$. Sua missiva foi

38 AHU-Castro e Almeida, cx.22, doc.4112. Carta de Botelho de Mattos (do próprio punho) para Thomé J oaquim da C. Corte Real, de 20/05/1759. A segunda parte da carta refere-se às comemorações pelo restabelecimento da saúde de D. J osé após o atentado. "Foy tal o prazer, com que todos receberão a feliz e alegre noticia de se achar o nosso Fidelissimo Soberano inteyramente restituido a sua saude e dispozição, que não he necessario ouvilos, basta velos para se vir no conhecimento do natural alvoroço, e alegria dos seos corações. Não há Igreja nesta cidade em que se não festeje e cante Te Deum em acção de graças pello elevado beneficio que Deos nos fez em conservar na estimada vassalagem de hum tal Monarca e sem embargo de serem continuos estes festejos he 0 concurso a elles cada vez mayor. / Bahia Mayo 20 de 1759".

390 documento é citado por Arlindo Rubert, op. cit., p. 33 e 241. É certo que até a notícia do atentado contra D. J osé o arcebispo não havia suspendido os jesuítas dos ministérios sagrados, contudo, como escreve Caeiro, quando tomou esta atitude ela já se revelava desnecessária, haja vista que os mesmos religiosos já se encontravam segregados. Cf. Caeiro, op. cit., p.82.

40 Cf. AHU, Bahia avulsos, CX.143, doc.10990. Minuta da Instrucção para o Marquez do Lavradio Dom Antonio Luiz de Almeyda, Vice Rey e Capitão General do Mar e Terra do Estado do Brazil (novembro de 1759). 
escrita, seguramente, antes que tivesse ciência do atentado contra D. J osé e da suposta participação dos jesuítas ${ }^{41}$. É possível que ao tomar conhecimento das notícias sobre o atentado, o prelado tenha se apercebido de seu mau passo, o que explicaria que em carta de 8 de junho de 1759 pedisse ao Secretário de Estado dos Negócios da Marinha "que na Prezença de S. Magestade queira S. Exa. desculpar os erros que os oitenta annos que elle Bispo tem de idade commetter no Seu Real Serviço"42. A bem da verdade, a atitude de Botelho de Mattos parece distante da "corajosa resistência" sugerida por Arlindo Rubert, que estabelece uma relação direta entre sua ação em defesa dos jesuítas e a renúncia ao arcebispado. Tal relação não tem nada de evidente, pois o último pedido de renúncia do arcebispo data de janeiro de 1759, antes, portanto, que o processo dos jesuítas tomasse o rumo que sabemos, acelerado pelas conclusões acerca do atentado contra D. J osé.

A reação moderada da coroa também é um indicativo de que 0 arcebispo não chegou a oferecer uma "corajosa resistência". Com efeito, mesmo ao reportar na instrução ao Marquês do Lavradio o temor de que o arcebispo fosse erigido à condição de chefe de um suposto partido pró-jesuíta e instruir que manifestasse o desagrado do monarca com a conduta do arcebispo, fica notório que a coroa imputa seu erro sobretudo à sua debilidade, fruto de sua idade provecta, instrumentalizada pela facção jesuítica ${ }^{43}$. Na mesma instrução, verifica-se que medidas mais duras contra o prelado - a exemplo da exigência do seu retorno imediato à corte de Lisboa - foram condicionadas ao fato de ele não se retirar da cidade e/ou agir como facção contrária aos interesses da coroa. Daí pedir que o Vice-Rei tivesse especial vigilância sobre os passos do arcebispo resignatário. Vigilância que deveria se estender aos membros do cabido e todo o clero regular para que pudesse atalhar, em seu nascedouro, qualquer tipo de excesso ${ }^{44}$.

41 Na minuta da instrução para o Marquês do Lavradio, lê-se: “Porque contudo aquellas grandes desordens do referido Arcebispo foram obradas antes de lhe haverem sido intimadas a Sentença de doze de janeiro deste presente anno [1759] compillada debaixo do numero doze da dita collecção, e das mais Leis, e Ordens que depois da mesma sentença mandei expedir..." Cf. AHU, Bahia avulsos, cx.143, doc.10990.

42 AHU, Castro e Almeida, cx.25, doc.4784.

43 Cf. AHU, Bahia avulsos, cx.143, doc.10990. "Tambem me acho com igual certeza informado de que os mesmos Regulares servind ose ou do artificio da referida hypocrezia, ou de suggestões fundadas na prepotencia, que sempre se atribuem para incutirem medos onde achão espiritos capazes de nelles fazerem impressão as suas ameaças, ou de quaesquer outros meyos semelhantes, entre os muitos de que a sua notoria malicia foi sempre fertilissima: Tem abusado inteiramente da debilidade em que os muitos annos precizamente hão de ter posto o Arcebispo da Bahia de sorte, que chegou a maquinar a favor das intrigas dos ditos Regulares com algumas pessoas da sua facção e chegou a precipitarse no desatinado absurdo de escrever para esta Corte que os mesmos Regulares erão uteis naquelle Arcebispado, sendo nelle tão atrozmente prejudiciaes, como he manifesto".

44 Idem. "Não permitindo a prudencia, nem que o referido Arcebispo fique conservado na cidade da Bahia em semeIhantes circunstancias, ainda depois da sua demissão, nem que Eu deixe de ter com elle algumas demonstrações de Meu Real dezagrado, e Supremo Poder depois de se haver percipitado nos intoleraveis absurdos, que deixo referidos: 0 mando logo sair da mesma cidade, e seu destricto pela outra Carta Regia que acompanhará esta, a qual lhe fareis entregar pelo Ouvidor Geral do Crime, no cazo em que elle per si mesmo não cuide em sair da cidade depois de haver feito a sua demissão, e de ver o governo entregue ao Cabido.

15. Sobre as mais cautellas, que deixo referidas, verá bem a vossa prudencia, que he insdispensavel a da exacta vigilancia, que deveis ter, não somente sobre os passos do dito Arcebispo, e sobre o comum do dito cabido, mas 
Os fatos posteriores tendem a esclarecer melhor a situação e, talvez, corroborar nossa hipótese de que não houve exatamente resistência por parte do arcebispo, nem a coroa moveu verdadeira perseguição contra ele. 0 relatório do Vice-Rei, Marquês do Lavradio, é eloqüente acerca do comportamento do arcebispo resignatário e do próprio governo em relação a ele. Da parte do arcebispo fica patente a consciência de ter desagradado, razão pela qual roga que the sejam perdoados os erros que por ventura cometera no serviço d'El Rei. Sem manifestarqualquer resistência, o prelado pede que se lhe permita retirar-se para a localidade de N. Sra. da Penha de Itapagipe, que fica no subúrbio de Salvador, a uma légua e meia do centro da cidade. Seis dias após a posse do Vice-Rei, e com sua autorização, o arcebispo "se retirou para o dito sitio, adonde me consta tem hido muito pouca gente e também me dizem que o sitio he muito doentio, em huma praya junto ao mar; as cazinhas são humildes; porem como tão somente se reduzio a hum capellão e dous negros, nellas cabe sufficientemente". Da parte do Marquês do Lavradio é notória a ausência de animosidade em relação ao prelado resignatário. Pelo contrário, há até elogio ao desprendimento material de Botelho de Mattos, "tão grande esmoller, que rezervando unicamente o precizo para a sua subsistência, tudo o mais repartia em esmollas, de forma tal, que brevemente se achava em estado de as pedir para modicamente se sustentar"45. Por trás deste elogio talvez houvesse a intenção de ajudar o arcebispo a continuar a receber sua côngrua para que pudesse se manter com alguma dignidade ${ }^{46}$. Afinal, no dia 3 de março, havia escrito em resposta à consulta do provedor-mór da Fazenda Real da Bahia acerca da continuidade do pagamento da côngrua ao arcebispo, que escrevesse ao rei perguntando-lhe como deveria proceder naquele caso, tendo em vista que ele vice-rei não tinha juris dição sobre aquele negócio ${ }^{47}$. Para além de demonstrar a boa vontade do vice-rei para com Botelho de Mattos, esta carta também suscita interesse por tocar num problema bastante recorrente naqueles autores que sustentam a versão da perseguição pombalina ao arcebispo da Bahia: o da suspensão do pagamento de sua côngrua.

Aqui, mais uma vez, Caeiro destaca-se entre os que denunciam a maldade do poderoso ministro de D. J osé. Com efeito relata que,

Segundo as ordens, que recebera de Carvalho mandou logo o desembargador Coutinho que se exarasse nas contas do tesouro que para o futuro se lhe não

tambem sobre hum dos capitulares delle que tiverem na cidade da Bahia alguma influencia, e sobre quaisquer outros clerigos que sejam revoltozos, ou ainda sobre quaesquer Regulares, que se achem nas mesmas circunstancias para que antes de obrarem algum excesso façaes exterminar para lugares remotos dos sertões alguns dos mesmos Eccleziasticos, que sirvão de exemplo aos outros para se cohibirem".

45 Cf. AHU, Castro e Almeida, cx.25, doc.4811.

46 Santos, Fabricio Lyrio, Te Deum Laudamus..., p.100, também sugere que se tratava de uma tentativa do Vice-Rei para sensibilizar a coroa quanto à situação de Botelho de Mattos.

47 Cf. AHU, Castro e Almeida, cx. 25, doc.4792-4795. 
desse mais nenhum dinheiro. Pelo que viria aquele venerado varão, não digno de viver em tempo de Pombal, a morrer à fome e mingua de todo o necessário, se a comiseração e generosidade dos fieis não acudira com as suas esmolas ao pobre morador do humilde tugúrio.

Tomando por base uma fonte romana, Arlindo Rubert também afirma que "para confirmar o ódio de Pombal contra o corajoso arcebispo, o Conselho Real por ele manejado mandou escrever nos Livros da Provedoria que não se lhe daria um centil, obrigando-0 a viver de esmolas"48.

A primeira dificuldade que encontramos nestes discursos que insistem na perseguição pombalina é a de harmonizar a atitude serena do Marquês do Lavradio em relação ao prelado resignatário com a idéia de que Carvalho devotava um ódio mortal ao mesmo. Ora, que homem de governo estaria disposto, àquela altura, a contrariar ou estorvar os desígnios do poderoso ministro? Uma outra dificuldade, esta relacionada às afirmações de Caeiro, tem a ver com as supostas esmolas dos fiéis. Não está claro que o retiro de Botelho de Mattos para Itapagipe visava justamente reduzir ao mínimo seu contato com a sociedade baiana? Como admitir, então, que os fiéis o tivessem acudido com suas esmolas? A hipótese é bastante improvável.

A partir da documentação do AHU é possível chegar a uma conclusão bem diferente a respeito do problema da continuidade do pagamento da côngrua ao arcebispo. Constata-se que, em vinte de fevereiro de 1760, Botelho de Mattos recebeu pouco mais de 536 mil réis relativos à côngrua e ordenado vencidos ${ }^{49}$, quantia suficiente para garantir a subsistência dele, do capelão e dos dois negros, que se encontravam sob seu serviço em Itapagipe, por um bom tempo. Em março do mesmo ano, verifica-se que 0 provedor-mór da Fazenda Real da Bahia faz subir a consulta à coroa para que se delibere quanto à continuidade do pagamento da côngrua. Por fim, uma busca detida nos códices do AHU permitiu-nos descobrir uma carta régia datada de 2 de abril de 1761 e dirigida ao mesmo Provedor-Mór, que preferimos transcrever integralmente, tendo em vista sua importância para a resolução do problema aqui tratado.

Dom J ozé Etc. Faço saber a vós Provedor mor da Fazenda Real da Bahia, que havendo visto o que me representastes em carta de 4 de março do anno proximo passado, dandome conta de que no dia sete de J aneiro do mesmo anno se tocara Sé vacante nessa cidade por eu aceitar ao Arcebispo D. J ozé Botelho de Matos a dimissão que fez do Arcebispado, o qual se devolvera ao cabido, que o exerce, e porque desde o primeiro de Novembro de 1759 até o sobredito já tinha vencido de congrua e ordenado o dito Prelado, quinhentos e trinta e seis mil cento e secenta e dous reis, cuja quantia recebera e por duvidares se devieis

48 Cf. Arlindo Rubert, op. cit., p.33. 0 autor apresenta como fonte um códice do Arquivo da Propaganda Fide - Amer. Merid. (1745-1766), cod.3, ff.465-466.

49 Cf. AHU, Castro e Almeida, cx. 25, doc. 4792-4795. 
continuar na prestação do mesmo ordenado por estar rezidindo o dito Prelado em hum sitio fora dessa cidade e não haver determinação ou ordem expressa minha que em tal cazo de providencia Representareis ao V. Rey desse Estado todo o referido, o qual vos ordenara me desseis conta para eu rezolver o que fosse servido, o que tudo me fazieis prezente para saberes o que devieis praticar neste cazo, ficando o dito Arcebispo na mesma parte em que se acha; e vendo juntamente o que sobre este particular responderão os Procuradores de minha Fazenda e Coroa: Hey por bem por minha Real rezolução de 27 do corrente anno, tomada em consulta do meu Conselho Ultramarino, que se continue esta congrua ao dito Arcebispo, emquanto eu não mandar o contrario, pagandoselhe o que tiver vencido até o prezente e assim o fareis praticar. El Rey Nosso Senhor o mandou pellos Conselheiros do seu Conselho Ultramarino abaixo asignados e se passou por duas vias. Manoel Antonio da Rocha a fez em Lisboa a 2 de Abril de $1761^{50}$.

\section{Considerações finais}

Não é raro, entre nós historiadores, que se faça cega confiança a construções que se estabelecem como verdades incontestes. Em boa medida, 0 objetivo deste artigo foi o de mostrar que há algo de artificial e impreciso na construção da imagem de Botelho de Mattos como paladino do anti-pombalismo e que é necessário repensar e analisar em nova chave a atitude do episcopado português no período pombalino, em particular na conjuntura crucial da expulsão dos jesuítas de Portugal e de seu Império.

No caso específico do prelado baiano é preciso compreender que as razões para o seu pedido de resignação da mitra parecem estar muito mais ligadas aos males da idade do que à sua simpatia em relação aos jesuítas. Eis um raro momento em que testemunhos governamentais e jesuíticos são unânimes: o velho arcebispo já não podia mais exercer seu múnus episcopal como outrora. Não deixa de ser interessante observarque, fazendo a devida inversão, o discurso da instrução ao Marquês do Lavradio e o de Caeiro acerca do arcebispo utilizam argumentos idênticos. Com efeito, se para a coroa os jesuítas abusaram da "debilidade em que os muitos annos precizamente hão de ter posto o Arcebispo da Bahia"51, para Caeiro era patente que a idade daquele prelado, já octogenário, deixava-o "mais exposto a impressionar-se com os furores de Carvalho"52. Mesmo Botelho de Mattos parecia estar de acordo com o problema da senilidade que ele menciona em carta a Tomé J. da Costa Corte Real, de junho de 1759, e também em sua carta de 30 de março de 1760, dirigida ao rei, na qual, após agradecer ao monarca por ter aceitado seu "dezistimento" da mitra, lembra que sua

50 AHU - Cod.250, fl.239. O sublinhado é nosso.

51 Cf. AHU, Bahia avulsos, cx.143, doc.10990.

52 Cf. Caeiro, op. cit., p.87. 
súplica tinha origem em seu desejo de "evitar o grande perigo em que via a minha salvação por não poder, como devia, satisfazer aos innumeraveis encargos desta Mitra; e se algua couza fazia era involto em tantas imperfeições que de mim proprio me escandalizava"53.

Por fim, é preciso oferecer ao menos algum início de resposta ao problema de saber por que Botelho de Mattos foi erigido à condição de um paladino da resistência às políticas antijesuíticas de Carvalho e Melo? Em 1910, após a implantação da República, os jesuítas foram mais uma vez expulsos de Portugal e muitos deles vieram para o Brasil. Talvez alguns destes religiosos tenham dado uma contribuição fundamental para a construção da memória de Botelho de Mattos como defensor dos jesuítas e herói antipombalino, na medida em que isto poderia ser útil à causa jesuítica. Sem dúvida, para jesuítas e ultramontanos de inícios e meados do século XX foi preciso encontrar vozes dissonantes no episcopado do mundo português para melhor atacar Pombal e o modelo de Igreja que legou para as gerações seguintes. 